\author{
EISSN:2706-7920 ISSN: 2077-4435 \\ DOI: $10.36632 / \mathrm{csi} / 2021.10 .1 .5$ \\ Journal homepage: www.curresweb.com \\ Pages: 43-57
}

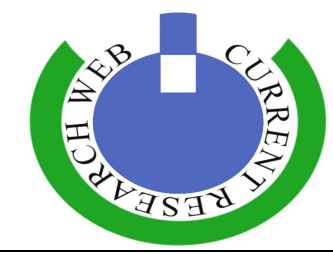

\title{
Effect of Alkaline Pre-Treatment of Some Straws as a Rapid Composting Process on Soil Properties and Crop Productivity
}

\author{
Abd Elghany S.H., Esmaeil M.A. and A.A. Arafat \\ Soils, Water and Environment Res. Inst., Agric. Res. Center, Giza, Egypt. \\ Received: 10 December $2020 \quad$ Accepted: 15 January $2021 \quad$ Published: 25 January 2021
}

\begin{abstract}
Field experiments were conducted to determine the effect of composts prepared by base pretreatment for two types of straws (rice and corn straws) on some soil properties and sorghum crop yield (summer 2019) and their residual effect on barley crop (winter 2019/2020) at Bahtim Research Station, Agriculture Research Center, Kalubia Governorate. Both rice straw and corn straw incubated with $2 \% \mathrm{KOH}$ for four weeks then at the end of incubation period each type of the incubated straw neutralized by sulphuric acid and citric acid separately to produced four different types of composts; composted rice straw neutralized by sulphuric acid (RS) composted rice straw neutralized by citric acid (RC), composted corn straw neutralized by sulphuric acid (CS) and composted corn straw neutralized by citric acid (CC). The four types of composts combined with soil in split plot design experiment under two nitrogen levels of (80 and 100 unit $\mathrm{fed}^{-1}$ ) to study their current and residual effects on each of soil properties, nutrient availability and yield of crops compared to control. The obtained results showed that a positive effect for all the different composted materials on soil chemical properties, nutrients availability and crops yield compared to control soil. The combination of different composted materials with soil decreased significantly the EC values followed the trend of $(\mathrm{RC})>(\mathrm{CC})>(\mathrm{RS})>(\mathrm{CS})$ during the first season and with slight effect through the second season. Also, there was a slight decrease in $\mathrm{pH}$ values with (RC) which recorded the lowest one particularly during the first season. On the other hand, application of different types of compost to soil significantly increased the soil (OM \%) during the both seasons compared to control. Moreover, available soil N, P and $\mathrm{K}$ increased significantly during the first season in the order $(\mathrm{RC})>(\mathrm{CC})>(\mathrm{RS})>$ (CS) with slight impact during the second season compared to control. Compost of (RC) and (CC) gave the highest yield of Sorghum in the first season and Barley in the second season than each of (RS) and (CS) compared to control. Generally, the base pretreatment method for different rice straw contributed in decreasing incubation period of composting process and produced beneficial types of compost aid to increase soil productivity.
\end{abstract}

Keywords: rice straw, corn straw, base pre-treatment, compost.

\section{Introduction}

The food chain, and high availability, with there being in the world between 3.7 and 5 billion metric tons of lingo-cellulosic waste, about 8.9 million from cereal wastes such as wheat, rice, and barley (Mahmood et al., 2019). In recent years, interest had increased in the use of agro-industrial wastes for use as raw materials in the production of second-generation biofuels and other products of industrial interest. A pretreatment is necessary, followed by an enzymatic hydrolysis to obtain high yields of fermentable sugars. Rice straw is considered to account for the largest portion of available biomass feedstock in the world, it considers as a raw material for the production of biofuels and biomaterials (Kim and Dale, 2004). However, rice

Corresponding Author: Abd Elghany S.H., Soils, Water and Environment Res. Inst., Agric. Res. Center, Giza, Egypt. E-mail: haassaann72@gmail.com 
straw contains large amounts of lignin and complex polysaccharides, which make it difficult to hydrolyze it to fermentable products. Therefore, pretreatment is an essential step in obtaining highly efficient degradation and fermentation. Thus far, both acid and alkaline pretreatments have been used to improve enzymatic accessibility (Akhtar, 2016). After pretreatment, the cellulose and hemicelluloses in rice straw can be easily hydrolyzed enzymatically into monosaccharides, and thus converted by microorganisms into biofuels and compost (Sheikh et al., 2015). Alkaline pre-treatment has been used to solubilize various substrates such as lignocellulosic materials. It allows significant solubilization and improves biodegradability performances (Millet et al., 1985 and Patel et al., 1993). Hydroxide addition caused the $\mathrm{pH}$ increase that was responsible for the chemical oxygen demand solubilization but also led to the formation of refractory compounds. For example, colored molecules were formed through reactions commonly named Maillard reactions (Penaud et al., 1999). Thermo-chemical pretreatment can be used to solubilize organic matter before biological treatment when complex substrates such as sludge are concerned (Huang et al., 1983 and Sawayama et al., 1995). The effect of such a pretreatment is to promote hydrolysis and to split complex polymers into smaller molecules (Dote et al., 1993). Many studies have focused on the determination of pretreatment conditions for improving solubilization and anaerobic biodegradability of waste activated sludge (Stuckey and MacCarty1978). Rice straw can be used in the production of energy or organic fertilizer. However, one of the main problems in the transformation of rice straw is its low-biodegradability. Alkaline pre-treatment involves the application of alkaline solutions like $\mathrm{NaOH}$ or $\mathrm{KOH}$ to remove lignin and a part of the hemicelluloses, and an increase in the accessibility of the enzyme to cellulose (Tarkov and Feist, 1969). Alkali pre-treatment can result in a sharp increase in saccharification yields. The main effect of sodium hydroxide pre-treatment on lingo-cellulosic biomass is delignification by breaking the ester bonds crosslinking lignin and xylan, thus increasing the porosity of biomass (Tarkov and Feist, 1969). Compounds such as cellulose are hardly decomposed by biological processes because of their recalcitrant and heterogeneous structure, primarily consisting of cellulose, hemicelluloses, and lignin (Chandra et al., 2007). Cellulose digestibility is enhanced by the alkali pre-treatment process. This process is more effective for lignin solubilization than the acid or hydrothermal processes (Alvira et al., 2010). Alkaline peroxide treatment (Zhu et al., 2010) and ammonia treatment among them, ammonia treatment is one of the most effective methods for enhancing the bio-degradation of complex materials (Kim and Lee 2005). Rapid pulping of rice straw was achieved by 10-min alkaline peroxide treatment. The resultant pulp consisted mainly of cellulose. High sugar yields were obtained following enzymatic hydrolysis of this alkaline peroxide treated rice straw (Hideno, 2017). The cooking of rice straw by aqueous ammonia mixed with a small amount of potassium hydroxide $(\mathrm{KOH})$, enriched the composted matrerials with nutrients such as potassium and nitrogen and used in fertilizer application (Rodríguez et al. (2008). Among chemical pretreatments, alkaline and alkaline peroxide methods in mild conditions have shown high effectiveness on several agricultural residues (Kumar and Wyman, 2009; Alvira et al., 2010). Alkaline and alkaline peroxide pretreatments at mild temperature have shown to be feasible methods in terms of sugars production from rice straw and hulls, respectively. Furthermore, it has been demonstrated that there is a positive correlation between biomass dissolution and hydrolysis yield, but up to solid loss of about $35.4 \%$ and $39.3 \%$ for rice straw and hulls, respectively ( Emir, 2014). On the other hand, alkaline pretreatment is considered as the most effective one with less sugar degradation, lower energy consumption, more lignin removal, and less furan derivatives (Behera et al., 2014; Whitfield et al., 2012). More importantly, with the salvation reactions (degradation), the alkaline pretreatment could swell the material, thus increase the internal surface area of the recovered solids and the accessibility of the enzymes (Jin et al., 2013). Qing et al. (2017) stated that alkaline pretreatment was more effective in delignification and enhancing enzymatic digestibility of pretreated soybean straw. The present work aims to discuss the composting of two types of agro-waste (rice straw and corn straw) in an incubation experiment under alkaline condition then combined with soil after neutralization by two types of acids (mineral acid and organic acid) and studying their impacts on soil chemical properties and yield of both sorghum and barley crops. 


\section{Materials and Methods}

\subsection{Field experiment}

A field experiment was carried out during summer season 2019 followed by winter season (2019/2020) in a clay loam soil at Bahtim Research Station, Agriculture Research Center, Kalubia Governorate, Egypt (Latitude 30 $0^{\prime} 31.316^{\prime \prime} \mathrm{N}$ and Longitude $31^{\circ} 16^{\prime} 53.714^{\prime \prime}$ E) to study the effect of integration of crop residues rice straw and maize treated by base and two rates of mineral nitrogen compared with recommended dose of mineral fertilizers (N, P and K) on Sorghum crop (Sorghumbicolor, cv. Giza 15) and their residual effect on cultivated of barley seeds (Hordeumvulgare L., cv. Giza 123).

\subsection{Soil samples}

Some soil physical and chemical properties of the experimental field were determined according to Page et al. (1982). Surface soil samples (0-30 cm depth) were collected from the experimental field before planting to determinate their chemical and physical properties. All soil samples were air dried, crushed and sieved through $2 \mathrm{~mm}$ sieved holes, and then were stored in plastic pages prior to analyses. Chemical and physical analyses of the soil are presented in Table (1).

\subsection{Alkaline pre-treatment}

20 kilograms of each rice straw and corn straw prepared in four plastic barrels (two barrels for each type) with a volume of $200 \mathrm{~L}$ were used for this purpose About $130 \mathrm{~L}$ of $2 \%$ potassium hydroxide solution was added to each drum as a base pretreatment for enhancing delignification process. The four barrels were left in open air for four weeks of incubation.

Table 1: Chemical and physical properties of the investigated soil

\begin{tabular}{|c|c|c|c|c|c|c|}
\hline \multirow{2}{*}{$\begin{array}{c}\text { pH } \\
(1: 2.5)\end{array}$} & \multirow{2}{*}{$\begin{array}{c}\text { EC } \\
\text { dS } \mathbf{~ m}^{-1}\end{array}$} & \multirow{2}{*}{$\begin{array}{l}\text { O.M } \\
(\%)\end{array}$} & \multicolumn{4}{|c|}{ Particle size distribution } \\
\hline & & & Sand $(\%)$ & Silt (\%) & Clay $(\%)$ & Textural Class \\
\hline 7.63 & 2.1 & 1.11 & 27.0 & 34.5 & 38.5 & Clay loam \\
\hline $\mathrm{CaCO}_{3}$ & SAR & SWC & \multicolumn{4}{|c|}{ Soil available $\mathbf{N}, \mathbf{P}$ and $\mathrm{K}(\mathrm{ppm})$} \\
\hline$(\%)$ & $(\%)$ & $(\%)$ & $\mathbf{N}$ & & $\mathbf{P}$ & $\mathbf{K}$ \\
\hline 3.2 & 5.51 & 52.0 & 24.27 & & 6.95 & 28.71 \\
\hline \multicolumn{4}{|c|}{ Souble cations $\left(\mathrm{meq} / \mathbf{L}^{-1}\right)$} & \multicolumn{3}{|c|}{ Souble anions $\left(\mathrm{meq} / \mathbf{L}^{-1}\right)$} \\
\hline $\mathbf{C a}^{+2}$ & $\mathrm{Mg}^{+2}$ & $\mathrm{Na}^{+}$ & $\mathbf{K}^{+}$ & $\mathrm{CO}_{3}{ }^{-2}$ & $\mathrm{HCO}_{3}^{-}$ & $\mathrm{SO}_{4}^{-2}$ \\
\hline 5.81 & 4.35 & 12.41 & 0.45 & - & 1.11 & 11.00 \\
\hline
\end{tabular}

SAR: Sodium adsorbed ratio. SWC: Saturation water content

\subsection{Chemical analysis}

The samples of incubated materials were taken after one, two, three and four weeks of incubation. The samples were dried and grounded to pass through $2 \mathrm{~mm}$ sieve for chemical analysis of carbon, nitrogen, phosphorus and potassium. Total organic $\mathrm{C}$ in the compost was measured by the method of Nelson and Sommers (1982) and total $\mathrm{N}$ was measured by Kjeldahl's digestion method (Bremner and Mulvaney, 1982). Phosphorus determined by (Watanabe, and Olsen, 1965) method. Sodium and potassium were determined by flame photometer (Jackson, 1967). The humic acid extraction was conducted using the procedures described by Ahmed et al. (2004). Humication percent was determined by the gravimetric method of (Campbell et al., 1967). Some chemical analyses of rice and corn straw before the incubation experiment and their chemical compositions during incubation stages $\left(1^{\text {st }}, 2^{\text {nd }}, 3^{\text {rd }}\right.$ and $4^{\text {th }}$ week) were determined as shown in Tables (2 and 3 ).

After plant harvesting, soil samples were collected from experimental plots at $0-30 \mathrm{~cm}$ soil depth, in the two seasons. The soil samples were air dried and analyzed for some chemical characteristics, i.e. soil EC $\left(\mathrm{ds} . \mathrm{m}^{-1}\right), \mathrm{pH}$, organic matter and total calcium carbonate were estimated according to the methods described by Cottenie et al. (1982). Particle size distribution was carried out by the pipette method described by Gee and Bauder (1986) using sodium hexameta phosphate as a dispersing agent. Soil nitrogen content was determined by micro 
Kjeldahl method according to Jackson (1973). While the content of available macronutrients phosphorus and potassium was determined according to the methods described by Cottenie et al. (1982).

Table 2: Some chemical analyses of rice and corn straw before the incubation experiment.

\begin{tabular}{lcc}
\hline Parameter & Rice straw & Corn straw \\
\hline $\mathbf{N \%}$ & 0.71 & 0.64 \\
$\mathbf{P \%}$ & 0.23 & 0.21 \\
K\% & 1.45 & 1.65 \\
Total carbon\% & 39.92 & 36.01 \\
Maximum extracted humate \% & 14.15 & 12.52 \\
\hline
\end{tabular}

Table 3: Chemical analyses of different types of straw during the incubation periods.

\begin{tabular}{lcccccccc}
\hline Parameters & \multicolumn{4}{c}{ Rice straw } & \multicolumn{5}{c}{ Corn straw } \\
\cline { 2 - 9 } & $\mathbf{1}^{\text {st }}$ & $\mathbf{2}^{\text {nd }}$ & $\mathbf{3}^{\text {rd }}$ & $\mathbf{4}^{\text {th }}$ & $\mathbf{1}^{\text {st }}$ & $\mathbf{2}^{\text {nd }}$ & $\mathbf{3}^{\text {rd }}$ & $\mathbf{4}^{\text {th }}$ \\
\hline$* \mathbf{N \%}$ & trace & 0.12 & 0.39 & 0.63 & trace & 0.13 & 0.31 & 0.51 \\
$* \mathbf{P \%}$ & trace & 0.10 & 0.13 & 0.18 & trace & 0.08 & 0.12 & 0.15 \\
$* \mathbf{K \%}$ & 2.12 & 2.32 & 2.63 & 3.10 & 2.01 & 2.42 & 2.71 & 2.80 \\
Residual fibre\% & 95.44 & 88.30 & 75.35 & 59.21 & 97.64 & 90.30 & 78.05 & 63.73 \\
Humication \% & 3.12 & 8.14 & 12.23 & 13.35 & 2.29 & 7.33 & 10.66 & 10.72 \\
\hline
\end{tabular}

*Extracted form

\subsection{Neutralization step:}

After ending incubation period; The first and third drums neutralized by diluted solution of $\mathrm{H}_{2} \mathrm{SO}_{4}(10 \% \mathrm{w} / \mathrm{v})$ to about $\mathrm{pH} 7$ to form potassium sulphate, whereas the second and fourth drums neutralized by citric acid solution of $(10 \% \mathrm{w} / \mathrm{v})$ to the same $\mathrm{pH}$ and potassium citrate was formed instead. Four types of compost were formed; composted rice straw neutralized by sulphuric acid (RS), composted rice straw neutralized by citric acid (RC), composted corn straw neutralized by sulphuric acid (CS), and composted corn straw neutralized by citric acid (CC). The plots were treated as shown in Table (4).

Table 4: The experiment plot treatments

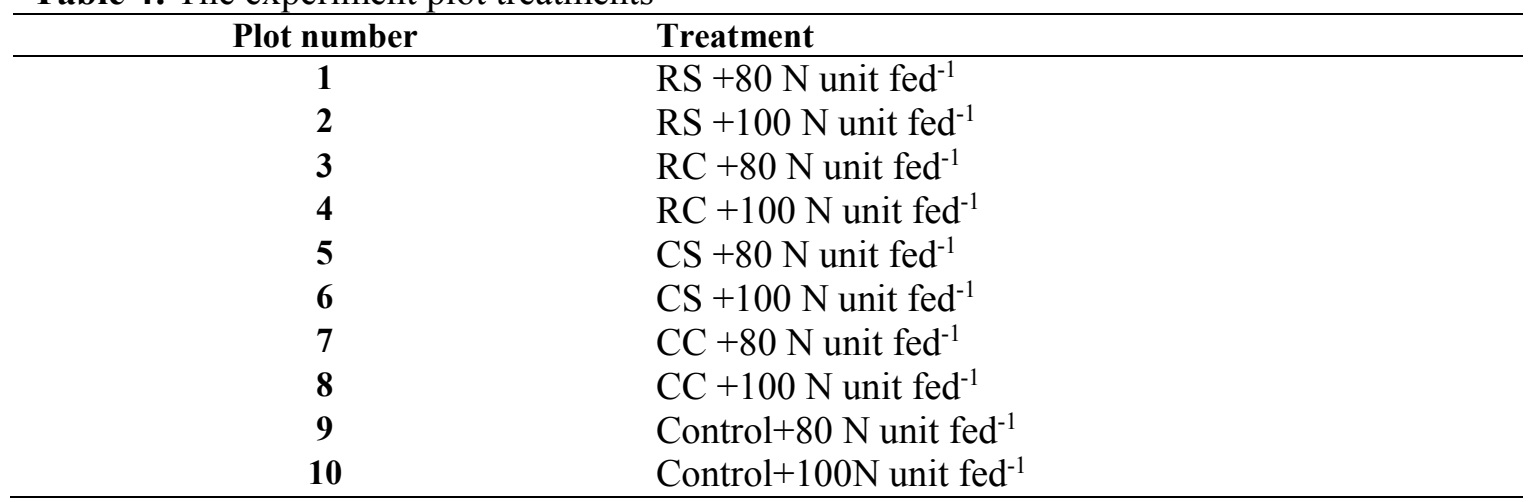

\subsection{Experimental design:}

Split plot design filed experiment was carried out with three replicates during two successive seasons at Agricultural Research Station farm in Bahtem, Kalubia Governorate, Egypt. Sorghum was selected as an indicator crop to evaluate the effect of different types of compost as a soil amendment then followed by planting barley to study the residual effect of these conditioners. The main plot was two doses of nitrogen treatments 80 and 100 unit fed $^{-1}$. The sub main plots were the four types of compost; (RS), (RC), (CS), and (CC). The chemical analysis of four types of compost listed in Table (5). 
Table 5: Selected chemical properties of composting materials after neutralization.

\begin{tabular}{|c|c|c|c|c|}
\hline Parameter & RS & RC & CS & $\mathrm{CC}$ \\
\hline Moisture content\% & 22.31 & 20.15 & 21.22 & 20.50 \\
\hline pH & 7.37 & 7.35 & 7.39 & 7.36 \\
\hline $\mathrm{EC} \mathrm{dS} \mathrm{m^{-1 }}$ & 5.19 & 5.16 & 5.30 & 5.28 \\
\hline$* \mathbf{N \%}$ & 0.47 & 0.51 & 0.40 & 0.42 \\
\hline *P\% & 0.14 & 0.15 & 0.11 & 0.13 \\
\hline *K\% & 2.48 & 2.53 & 2.24 & 2.27 \\
\hline Residual fiber \% & 48.22 & 48.01 & 51.29 & 51.20 \\
\hline Extracted humate & 10.68 & 10.73 & 8.55 & 8.67 \\
\hline
\end{tabular}

*Extracted form

All the subplots treatments consisted of four types of compost soil amendments were incorporated into the soil at the rate of $\left(0.5 \mathrm{~kg} / \mathrm{m}^{-2}\right)$. Phosphorus and potassium were applied with a rate of $23.25 \mathrm{~kg} \mathrm{P}_{2} \mathrm{O}_{5}$ fed $^{-1}$ and $24 \mathrm{Kg} \mathrm{K}_{2} \mathrm{O}$ fed ${ }^{-1}$ in the forms of superphosphate $(15.5 \%$ $\left.\mathrm{P}_{2} \mathrm{O}_{5}\right)$ and potassium sulfate $\left(48 \% \mathrm{~K}_{2} \mathrm{O}\right)$, respectively, before planting. While, nitrogen was applied as ammonium nitrate $(33.5 \% \mathrm{~N})$ at a rate of 80 and $100 \mathrm{Kg} \mathrm{N} \mathrm{fed}^{-1}$, in two equal doses after complete germination and before the emergence of spikes. Sorghum grains were sown at the rate of $7 \mathrm{Kg} . \mathrm{fed}^{-1}$. After Sorghum crop harvest, barley was sown the rate of $60 \mathrm{~kg} / \mathrm{fed}$ under the same treatments to study the residual effect of the treatments.

\subsection{Statistical analysis:}

All measurements were carried out in triplicate. The one-way analysis of variance (ANOVA) was carried out to determine the statistical significance of the treatment effects with Duncan grouping procedure at $\mathrm{p}=0.05$ by using SPSS and SAS software programs.

\section{Results and Discussion}

\subsection{Soil chemical properties:}

\subsubsection{The first season:}

The data showed in Table (6) revealed that there were significant differences for all types of composted materials on the chemical properties (EC, $\mathrm{pH}$, and organic matter $\mathrm{OM} \%$ ) of investigated soil compared to control. Electrical conductivity is a soil parameter that indicates indirectly the total concentration of soluble salts and is a direct measurement of salinity (Angelova et al., 2013). The effect of composted materials on EC of soil under investigation decreased significantly the $\mathrm{EC}$ values relative to the control, in the order of, composted rice straw neutralized by citric acid (RC) $>$ composted corn straw neutralized by citric acid $(\mathrm{CC})>$ composted rice straw neutralized by sulphuric acid (RS) $>$ composted corn straw neutralized by sulphuric acid $(\mathrm{CS})>$ control where the recorded mean values were 1.28, 1.39, 1.63, 1.70 and 2.25 ds. $\mathrm{m}^{-1}$ respectively. On the other hand mixing the different types of composted materials with soil under nitrogen doses $\left(80,100\right.$ unit fed $\left.^{-1}\right)$ showed insignificant decreasing in EC values of the soil whereas the recorded data were $1.55,1.44 \mathrm{ds} . \mathrm{m}^{-1}$ for both nitrogen doses of 80,100 unit $\mathrm{fed}^{-1}$, respectively. The significant decreasing in EC of the soil may be attributed to the degree of humification of composted materials which impart them water retention properties that when combined with soils retain some amount of irrigation water then decreasing the electrical conductance of the treated soils by diluting the dissolved salts around root zoon. These results agreed with Hoda (2019) who observed that the addition of different rates of compost (as organic amendments), during the first and second seasons leaded to the reduction of soil EC values relative to control. Rady et al. (2016) concluded that the effect of orgnometallic fertilizer OMF compost application at 20 ton. ha $^{-1}$ during two seasons of cultivation were highly significantly effective in reducing soil $\mathrm{ECe}$ and $\mathrm{pH}$ values.

Also Jiangkuan et al. (2016) found that, more exchangeable $\mathrm{Na}^{+}$was replaced from the soil colloid receiving humic substances. Moreover, Lakhdar et al. (2009) emphasized that the organic matter presence in humified materials decreased soil $\mathrm{Na}, \mathrm{EC}$ and $\mathrm{pH}$ values due to high supplies of essential cations. EC and ESP were positively affected by amino acids and humic 
acids application as compared to control treatment, and this may be attributed to that these substances have the ability to chelate ions so convert them to easily leaching salts (Mona, 2017).

Concerning the effect of different types of composted materials on $\mathrm{pH}$ values of the treated soils, the data tabulated in table (6) declared that there were slightly decline in $\mathrm{pH}$ values where (RC) recorded the lowest one 7.89 whereas the control was the highest one 8.28. Also there were insignificant results in $\mathrm{pH}$ changes of the soil due to mix the soil by different types of composted materials at both nitrogen doses of 80, 100 unit fed $^{-1}$ where the corresponding values were 8.08, 8.02 respectively. Khaled and Fawy (2011) stated that the reduced $\mathrm{pH}$ value of the soil was due to the replacement of the soil solution of salt ions with $\mathrm{H}^{+}$of humic substances which caused the $\mathrm{pH}$ of the solution to decrease. The reduction in $\mathrm{pH}$ values could be attributed to the accumulation of active organic acids soil (Rady et al., 2016). Addition of humic substances can suppress excess $\mathrm{Na}$ and $\mathrm{Ca}$, thus reducing toxic and osmotic effects, causing soil $\mathrm{pH}$ and $\mathrm{EC}$ to go down and nutrient availability for the plant to increase (Mindari et al., 2019).

Application of compost to the investigated soils during the first and second seasons gave highly significant decreasing to the soil $\mathrm{pH}$ relative to control (Hoda, 2019). Also she suggested that these decreases in soil $\mathrm{pH}$ compared to control induced by the addition of compost treatments could be attributed to the acidic effect of decomposable products of organic materials. Soil $\mathrm{pH}$ can be decreased after application of compost from rice straw mixed with agro-industrial wastes due to the release of $\mathrm{H}^{+}$via nitrification and/or the production of organic acids during decomposition (Rashad et al., 2011). Also, addition of compost from manure had been reported to both increase and decrease soil $\mathrm{pH}$ and has the ability to buffer soil $\mathrm{pH}$ (Johnson et al., 2006).

Regarding to the effect of composted materials on organic matter content (OM \%) within the soil, the data presented in table (6) illustrated that there was a significant increase in (OM $\%$ ) due to mixing the soil with different types of composted straw followed the trend of (RC) $>$ $(\mathrm{CC})>(\mathrm{RS})>(\mathrm{CS})>$ control. Whereas the corresponding data were $2.46,2.43,2.34,2.23$ and $1.19 \%$, respectively and there were a nearly effect between both (RC), (CC) on organic matter content within the soil. On the other hand and the same trend there were insignificant changes in OM \% for mixing the soil by different types of composted materials at nitrogen doses of 80 , 100 unit $\mathrm{fed}^{-1}$ where the corresponding values were $2.33,2.40 \%$ respectively. The results agreed with Mona (2017) who stated that the mixing of the amino acids, humic substance or their combinations with soil significantly increased soil organic matter (O.M). Also it improves the soil fertility where compost increases the soil organic matter SOM content and modifies the chemical, physical and biological properties of the soil (Ceccanti et al., 2007). Moreover, the added compost can lead to significant changes in the composition of SOM and minimize carbon (C) mineralization from the soil (Nardi et al., 2004). The addition of mature compost improves soil properties by increasing the soil total organic carbon content and this depends on the characteristics and the amount of compost used (Tambone et al., 2013).

\subsubsection{The second season:}

The data presented in table (6) showed that there were slightly significant differences in chemical properties of the soil due to the residual effect of different composted materials which added during the first season. Respect to the EC of the soil; the control soil recorded the highest value $2.25 \mathrm{dS} \mathrm{m}^{-1}$ whereas there were insignificant results between both of (RS), (CS) where the recommended data was $1.72,1.76 \mathrm{dS} \mathrm{m}^{-1}$, respectively. The lowest EC values were for both (RC), (CC) with no significant effect between each other where the corresponding data were $1.59,1.63 \mathrm{dS} \mathrm{m}^{-1}$, respectively. In contrast there were insignificant changes of the EC values for the soils treated with nitrogen doses 80 or 100 unit fed $^{-1}$ due to the residual effect of composted materials where the corresponding values were $1.70,1.64 \mathrm{dSm}^{-1}$ for both 80,100 unit fed $^{-1}$, respectively.

Concerning to the residual effect of different composted materials on $\mathrm{pH}$ values of treated soils during the second season there were a slight decline in soil $\mathrm{pH}$ in all the treatments compared to control, where the residual effect of $(\mathrm{RC})$ recorded the lowest value 8.02 compared 
to control value 8.32. Also there were no significant results in $\mathrm{pH}$ values between nitrogen treatments 80 and 100 unit fed $^{-1}$ due to the residual effect of all composted materials where the corresponding values were $8.15,8.08$ for both nitrogen doses 80 and100 unit fed ${ }^{-1}$, respectively. As respect to the residual effect of composted materials on organic matter content (OM \%) within the soil during the second season, the data showed in table (5) declared that there were significantly increasing among all treatments in (OM \%) content within the soil returning to the residual effect of composted materials compared to control soil. Where the highest organic matter content value was $2.26 \%$ for (RC) followed by (RS) and (CS) which had a near effect on $(\mathrm{OM} \%)$ content where the corresponding data were $2.08,2.17 \%$ respectively followed by (CC) $1.97 \%$ compared to control value which was $1.31 \%$. It can be concluded that there were nonsignificant changes in (OM \%) values in the soil due to the residual effect of the composted materials through the second season under both nitrogen doses 80 and 100 unit fed $^{-1}$, where the corresponding data were $2.07,2.17 \%$, respectively.

Weber et al. (2007) found that short-term effects on soil properties with lower doses of composts, ( 1 and 5 months after compost application) that disappear thereafter. Chakim et al. (2020) found in their study on the effect of compost application to soil that the current and residual effects of compost have improved many soil chemical properties. Also they stated that soil organic matter (SOM), regarded as a key factor in determining soil fertility and productivity, where it increased $108 \%$ in the current season and $104 \%$ in the residual effect during the second season. In a rice-wheat rotation, Sarwar et al. (2008) reported that a rise in SOM content from 0.56 to $0.98 \%$ after rice cultivation and from 0.67 to $1.30 \%$ after wheat cultivation with the application of compost by a rate $24 \mathrm{tha}^{-1}$.

Table 6: The average values of $\mathrm{EC}, \mathrm{pH}$, and $\mathrm{OM} \%$ of two seasons of cultivation for different composted materials.

\begin{tabular}{|c|c|c|c|c|c|c|c|c|c|c|}
\hline \multirow{3}{*}{ Treatment } & & \multirow{2}{*}{\multicolumn{2}{|c|}{$\begin{array}{c}\text { EC dS m m } \\
\text { Nitrogen } \\
\text { dose }\end{array}$}} & \multirow{3}{*}{ Mean } & \multirow{2}{*}{\multicolumn{2}{|c|}{$\begin{array}{c}\text { pH } \\
\begin{array}{c}\text { Nitrogen } \\
\text { dose }\end{array} \\
\end{array}$}} & \multirow{3}{*}{ Mean } & \multirow{2}{*}{\multicolumn{2}{|c|}{$\begin{array}{c}\text { OM \% } \\
\begin{array}{c}\text { Nitrogen } \\
\text { dose }\end{array} \\
\end{array}$}} & \multirow{3}{*}{ Mean } \\
\hline & & & & & & & & & & \\
\hline & & 80 & 100 & & 80 & 100 & & 80 & 100 & \\
\hline & RS & 1.68 & 1.57 & $1.63^{\mathrm{c}}$ & 8.12 & 8.04 & $8.08^{c}$ & 2.30 & 2.37 & $2.34^{\mathrm{b}}$ \\
\hline Sorghum & RC & 1.32 & 1.24 & $1.28^{\mathrm{e}}$ & 7.92 & 7.86 & $7.89^{d}$ & 2.43 & 2.50 & $2.46^{\mathrm{a}}$ \\
\hline First & CS & 1.76 & 1.63 & $1.70^{\mathrm{b}}$ & 8.21 & 8.15 & $8.18^{b}$ & 2.20 & 2.26 & $2.23^{c}$ \\
\hline \multirow[t]{8}{*}{ season } & $\mathrm{CC}$ & 1.44 & 1.34 & $1.39^{\mathrm{d}}$ & 8.06 & 8.01 & $8.04^{c}$ & 2.40 & 2.45 & $2.43^{\mathrm{a}}$ \\
\hline & Mean & $1.55^{\mathrm{A}}$ & $1.44^{\mathrm{A}}$ & & $8.08^{\mathrm{A}}$ & $8.02^{\mathrm{A}}$ & & $2.33^{\mathrm{A}}$ & $2.40^{\mathrm{A}}$ & \\
\hline & Control & 2.16 & 2.33 & $2.25^{\mathrm{a}}$ & 8.27 & 8.29 & $8.28^{\mathrm{a}}$ & 1.17 & 1.21 & $1.19^{\mathrm{d}}$ \\
\hline & $\operatorname{LSD}_{(0.05) \text { straw }}$ & & & 0.036 & & & ns & & & 0.033 \\
\hline & $\operatorname{LSD}_{(0.05) \text { nitrogen dose }}$ & & & 0.122 & & & ns & & & 0.08 \\
\hline & $\operatorname{LSD}_{(0.05) \text { interaction }}$ & & & 0.032 & & & $\mathrm{~ns}$ & & & 0.005 \\
\hline & & & & Mean & & & Mean & & & Mean \\
\hline & $\mathbf{R S}$ & 1.76 & 1.68 & $1.72^{\mathrm{b}}$ & 8.19 & 8.13 & $8.16^{\mathrm{b}}$ & 2.05 & 2.11 & $2.08^{\mathrm{b}}$ \\
\hline Barley & RC & 1.59 & 1.58 & $1.59^{\mathrm{c}}$ & 8.05 & 7.99 & $8.02^{\mathrm{c}}$ & 2.22 & 2.30 & $2.26^{\mathrm{a}}$ \\
\hline Second & CS & 1.80 & 1.71 & $1.76^{\mathrm{b}}$ & 8.25 & 8.17 & $8.21^{b}$ & 1.89 & 2.05 & $1.97^{\mathrm{c}}$ \\
\hline \multirow[t]{6}{*}{ season } & $\mathbf{C C}$ & 1.66 & 1.59 & $1.63^{\mathrm{c}}$ & 8.12 & 8.04 & $8.08^{c}$ & 2.13 & 2.20 & $2.17^{b}$ \\
\hline & Mean & $1.70^{\mathrm{A}}$ & $1.64^{\mathrm{A}}$ & & $8.15^{\mathrm{A}}$ & $8.08^{\mathrm{A}}$ & & $2.07^{\mathrm{A}}$ & $2.17^{\mathrm{A}}$ & \\
\hline & Control & 2.21 & 2.29 & $2.25^{\mathrm{a}}$ & 8.31 & 8.33 & $8.32^{\mathrm{a}}$ & 1.27 & 1.35 & $1.31^{\mathrm{d}}$ \\
\hline & LSD $_{(0.05) \text { straw }}$ & & & 0.041 & & & ns & & & 0.07 \\
\hline & $\operatorname{LSD}_{(0.05)}$ nitrogen dose & & & 0.09 & & & ns & & & ns \\
\hline & $\operatorname{LSD}_{(0.05) \text { interaction }}$ & & & ns & & & ns & & & ns \\
\hline
\end{tabular}

(RS) composted rice straw neutralized by sulphuric acid, (RC) composted rice straw neutralized by citric acid, (CS) composted corn straw neutralized by sulphuric acid, (CC) composted corn straw neutralized by citric acid, ns: not significant, the same letters meaning insignificant effect.

\subsection{The effect of different composted straw materials on the soil fertility:}

\subsubsection{First season:}

The data presented in Table (7) emphasized that there were significant differences for all types of composted materials on the soil macro nutrients (N P K) compared to control. Respect to water soluble nitrogen within soil, the largest effect was for (RC) $41.08 \mathrm{ppm}$ followed by 
(CC) and (RS) which gave nearest significant effect on availability of water soluble soil nitrogen, where the corresponding values were 38.31 and $36.19 \mathrm{ppm}$, respectively followed by (CS) $35.27 \mathrm{ppm}$ then finally the control which was $29.33 \mathrm{ppm}$. Even though there were no significant treatment effects for all composted materials on water soluble soil nitrogen under both nitrogen doses $\left(80,100\right.$ unit fed $\left.^{-1}\right)$ where the corresponding data were $36.49,38.93 \mathrm{ppm}$, respectively. Regard to water soluble soil $\mathrm{P}$ availability by the impact of different composted materials, the (RC) gave the highest availability of soil $\mathrm{P}$ among all treatments, where the corresponding value was $13.04 \mathrm{ppm}$ followed by (CC) $12.53 \mathrm{ppm}$ followed by (RS) $11.70 \mathrm{ppm}$ followed by (CS) $10.53 \mathrm{ppm}$ then control which ranked the lowest value $6.66 \mathrm{ppm}$.

Table 7: The average values of water soluble soil nutrients N, P, and k (ppm) of two seasons of cultivation for different composted materials.

\begin{tabular}{|c|c|c|c|c|c|c|c|c|c|c|}
\hline \multirow{3}{*}{ Treatment } & & \multicolumn{2}{|c|}{$\mathbf{N}$} & \multirow{3}{*}{ Mean } & \multicolumn{2}{|c|}{$\mathbf{P}$} & \multirow{3}{*}{ Mean } & \multicolumn{2}{|c|}{$\mathbf{K}$} & \multirow{3}{*}{ Mean } \\
\hline & & \multicolumn{2}{|c|}{ Nitrogen dose } & & \multicolumn{2}{|c|}{ Nitrogen dose } & & \multicolumn{2}{|c|}{ Nitrogen dose } & \\
\hline & & 80 & 100 & & 80 & 100 & & 80 & 100 & \\
\hline & $\mathbf{R S}$ & 35.24 & 37.14 & $36.19^{\mathrm{ab}}$ & 11.32 & 12.08 & $11.70^{\mathrm{b}}$ & 40.30 & 40.94 & $40.62^{\mathrm{a}}$ \\
\hline Sorghum & RC & 39.31 & 42.84 & $41.08^{\mathrm{a}}$ & 12.45 & 13.62 & $13.04^{\mathrm{a}}$ & 41.60 & 42.85 & $42.23^{\mathrm{a}}$ \\
\hline First & CS & 34.53 & 36.00 & $35.27^{\mathrm{c}}$ & 10.28 & 10.77 & $10.53^{c}$ & 39.61 & 40.10 & $39.86^{\mathrm{a}}$ \\
\hline \multirow[t]{6}{*}{ season } & $\mathbf{C C}$ & 36.88 & 39.74 & $38.31^{\mathrm{ab}}$ & 12.11 & 12.95 & $12.53^{\mathrm{ab}}$ & 40.99 & 41.55 & $41.27^{\mathrm{a}}$ \\
\hline & Mean & $36.49^{\mathrm{A}}$ & $38.93^{\mathrm{A}}$ & & $11.54^{\mathrm{A}}$ & $12.36^{\mathrm{A}}$ & & $40.63^{\mathrm{A}}$ & $41.36^{\mathrm{A}}$ & \\
\hline & Control & 21.35 & 25.32 & $29.33^{\mathrm{d}}$ & 5.51 & 7.80 & $6.66^{\mathrm{d}}$ & 25.22 & 30.53 & $27.88^{b}$ \\
\hline & $\operatorname{LSD}_{(0.05) \text { straw }}$ & & & 4.46 & & & 0.79 & & & 5.75 \\
\hline & $\operatorname{LSD}_{(0.05) \text { nitrogen dose }}$ & & & ns & & & $\mathrm{ns}$ & & & ns \\
\hline & $\operatorname{LSD}_{(0.05) \text { interaction }}$ & & & ns & & & ns & & & ns \\
\hline \multirow{10}{*}{$\begin{array}{l}\text { Barley } \\
\text { Second } \\
\text { season }\end{array}$} & & & & Mean & & & & & & Mean \\
\hline & $\mathbf{R S}$ & 28.83 & 29.34 & $29.08^{\mathrm{a}}$ & 8.44 & 9.60 & $9.03^{\mathrm{bc}}$ & 32.72 & 32.94 & $32.83^{\mathrm{a}}$ \\
\hline & RC & 30.44 & 32.43 & $31.44^{\mathrm{a}}$ & 10.12 & 10.46 & $10.29^{\mathrm{a}}$ & 33.35 & 33.65 & $33.50^{\mathrm{a}}$ \\
\hline & CS & 28.29 & 29.21 & $28.75^{\mathrm{a}}$ & 7.81 & 8.79 & $8.30^{\mathrm{c}}$ & 32.22 & 32.61 & $32.42^{\mathrm{a}}$ \\
\hline & $\mathbf{C C}$ & 29.90 & 30.91 & $30.41^{\mathrm{a}}$ & 9.23 & 9.48 & $9.35 \mathrm{a}^{\mathrm{b}}$ & 32.83 & 33.18 & $33.01^{\mathrm{a}}$ \\
\hline & Mean & $29.37^{\mathrm{A}}$ & $30.48^{\mathrm{A}}$ & & $8.90^{\mathrm{A}}$ & $9.58^{\mathrm{A}}$ & & $32.78^{\mathrm{A}}$ & $33.10^{\mathrm{A}}$ & \\
\hline & Control & 17.02 & 20.15 & $18.58^{\mathrm{a}}$ & 5.83 & 6.48 & $6.15^{\mathrm{d}}$ & 18.80 & 19.27 & $19.03^{\mathrm{b}}$ \\
\hline & LSD $_{(0.05) \text { straw }}$ & & & ns & & & 0.69 & & & 3.38 \\
\hline & $\operatorname{LSD}_{(0.05) \text { nitrogen dose }}$ & & & ns & & & ns & & & ns \\
\hline & $\operatorname{LSD}_{(0.05) \text { interaction }}$ & & & ns & & & $\mathrm{ns}$ & & & $\mathrm{ns}$ \\
\hline
\end{tabular}

(RS) composted rice straw neutralized by sulphuric acid, (RC) composted rice straw neutralized by citric acid, (CS) composted corn straw neutralized by sulphuric acid, (CC) composted corn straw neutralized by citric acid, ns: not significant, the same letters meaning insignificant effect.

Also combining the different types of composted materials with soil under nitrogen doses $\left(80,100\right.$ unit $\left.\mathrm{fe}^{-1}\right)$ declare insignificant results in water soluble soil $\mathrm{P}$ availability where the corresponding data were $11.54,12.36 \mathrm{ppm}$ for both nitrogen doses of $\left(80,100\right.$ unit fed $\left.^{-1}\right)$ respectively. On the other hand, there were significant differences for all types of composted materials compared to control on $\mathrm{K}$ availability within soil in spite of there were slightly difference effects among them whereas the recorded values were $(42.23,41.27,40.62,39.86$ and $27.88 \mathrm{ppm}$ ) for (RC), (CC), (RS), (CS) and control respectively. The results were correspondent with Hoda (2019) who found that The effect of all treatments of compost application rates on $\mathrm{N}, \mathrm{P}$ and $\mathrm{K}$ content in soil were high significantly increase. This may be attributed to the $\mathrm{pH}$ decreasing as a result of adding compost to the soil, which is responsible for nutrients availability in soils. El-Maaz et al. (2014) found that a general increase in nutrient supplying capacity of soils with addition of compost. All treatments compost and/or compost + recommended chemical fertilizer were affected on available Nitrogen, Phosphors and Potassium in calcareous soil (Awad 2002). Organic materials mineralization released from compost or compost + recommended chemical fertilizer are answerable of increase the nutrients availability in soil (EL-Etr et al., 2004). 


\subsubsection{The second season:}

Generally, there were small impacts for the composted materials under investigation on the availability of soil nutrients (N, P, K) during the second season (barley crop) as shown in Table (7). Where the data recorded for water soluble $\mathrm{N}$ with soil was $(31.44,30.41,29.08$, 28.75 and $18.58 \mathrm{ppm}$ ) for (RC), (CC), (RS), (CS) and control, respectively. Whereas there were slight effect for each of composted material on the two nitrogen treatments $\left(80\right.$ and 100 unit fed $^{-}$ $\left.{ }^{1}\right)$ during the second season where the water soluble nitrogen for dose $\left(80\right.$ unit fed $\left.^{-1}\right)$ recorded $29.37 \mathrm{ppm}$ whereas the corresponding value for $\left(100\right.$ unit fed $\left.^{-1}\right)$ was $30.48 \mathrm{ppm}$. Also, respect to water soluble soil P, the recorded data for (RC), (CC), (RS), (CS) and control were 10.29, 9.35, $9.03,8.30$ and $6.15 \mathrm{ppm}$, respectively with insignificant results trend. The same trend was observed for ( 80 and 100 unit fed $^{-1}$ ) doses where there were slightly effects for the different composted materials on the availability of water soil $\mathrm{P}$ at nitrogen doses of ( 80 and 100 unit fed $^{-}$ $\left.{ }^{1}\right)$ where the corresponding data were $8.90,9.58 \mathrm{ppm}$, respectively. On other hand the water soluble soil $\mathrm{K}$ for (RC), (CC), (RS) and (CS) recorded 33.50, 33.01, 32.83, 32.42 and 19.03 ppm respectively without insignificant differences among them whereas the corresponding value for control was $19.03 \mathrm{ppm}$. Also there were insignificant influences for both nitrogen treatments $\left(80\right.$ and 100 unit fed $\left.^{-1}\right)$ on increasing the availability of water soluble soil $\mathrm{K}$ where the corresponding data were 32.78 and $33.10 \mathrm{ppm}$, respectively. The data agreed with Motavalli et al. (1989) who found that residual effects of manure or compost application can maintain crop yield level for several years after manure or compost application ceases since only a fraction of the $\mathrm{N}$ and other nutrients in manure or compost become plant available in the first year after application. Eghball (1999) found that $40 \%$ of beef cattle feedlot manure $\mathrm{N}$ and $20 \%$ of compost $\mathrm{N}$ were plant available in the first year after application, indicating that about $60 \%$ of manure $\mathrm{N}$ and $80 \%$ of compost $\mathrm{N}$ became plant available in the succeeding years, assuming little or no loss of $\mathrm{N}$ due to $\mathrm{NO}_{3}-\mathrm{N}$ leaching or denitrification. Residual effects of organic materials on soil properties can be contributed to improvement in soil quality for several years after application ceases (Ginting et al., 2003). Organic matter, total $\mathrm{N}, \mathrm{NO}_{3}-\mathrm{N}$, and $\mathrm{P}$ levels were still elevated 4 yr after dairy manure application (Lund and Doss, 1980).

\subsection{The effect of different composted straw materials on the crop yield:}

The data presented in Table (8) and illustrated Fig. (1) declared that the effect of composted materials on yield of sorghum increased significantly followed the trend of, composted rice straw neutralized by citric acid (RC) more than composted corn straw neutralized by citric acid (CC) then the composted rice straw neutralized by sulphuric acid (RS) and composted corn straw neutralized by sulphuric acid (CS) which gave nearly the same effect on sorghum crop yield compared to control, whereas the corresponding data were 1.32, 1.25, $1.16,1.12$ and 0.71 ton fed, respectively. Also there were nonsignificant differences between the two nitrogen doses ( 80 and 100 unit fed $\left.^{-1}\right)$ on sorghum crop yield under the effect of all types of composted materials whereas the corresponding data were 1.08 and 1.14 ton fed-1, respectively. Regarding to the second season, there were slight competences of composted materials on the barley yield which followed the trend; the (RC) and (CC) which gave the highest impact on barley yield with closest results to each other followed by (RS) which had higher effect than (CS) compared to control whereas the corresponding data were 2.16, 2.09, $1.86,1.78$ and 1.32 ton $\mathrm{fed}^{-1}$, respectively. On other hand, there were nonsignificant effects for the two nitrogen doses $\left(80\right.$ and 100 unit fed $\left.^{-1}\right)$ on barley yield, where the corresponding values for them were 1.91 and 2.03 ton fed ${ }^{-1}$, respectively as shown in Table (8) and Fig.(2).

Compost application is reported to have a positive effect on the physicochemical and biological properties of the soil which often leads to higher crop growth and yield (Abedi et al., 2012). Grain yield was increased significantly by the application of compost together with inorganic fertilizers. The residual effect from 1 year application of compost and inorganic fertilizers also gave yield benefits up to $271 \%$. This indicates that farmers who cannot afford to apply compost every year could improve productivity by as much as $271 \%$ by applying compost every other year (Nigus et al., 2014). 
Curr. Sci. Int., 10(1): 43-57, 2021

Table 8: Average yield of both Sorghum and Barley crops (ton fed ${ }^{-1}$ ) during the two seasons of cultivation under the effect of different composted materials.

\begin{tabular}{|c|c|c|c|c|c|c|}
\hline \multirow[t]{3}{*}{ Treatment } & \multirow{2}{*}{\multicolumn{2}{|c|}{$\frac{\text { Sorghum ton fed }^{-1}}{\text { Nitrogen dose }}$}} & \multirow{3}{*}{ Mean } & \multirow{2}{*}{\multicolumn{2}{|c|}{$\begin{array}{c}\text { Barley ton fed }^{-1} \\
\text { Nitrogen dose }\end{array}$}} & \multirow{3}{*}{ Mean } \\
\hline & & & & & & \\
\hline & 80 & 100 & & 80 & 100 & \\
\hline RS & 1.12 & 1.20 & $1.16^{\mathrm{c}}$ & 1.80 & 1.91 & $1.86^{\mathrm{b}}$ \\
\hline $\mathbf{R C}$ & 1.28 & 1.35 & $1.32^{\mathrm{a}}$ & 2.09 & 2.22 & $2.16^{\mathrm{a}}$ \\
\hline CS & 1.11 & 1.13 & $1.12^{\mathrm{c}}$ & 1.73 & 1.82 & $1.78^{\mathrm{c}}$ \\
\hline $\mathrm{CC}$ & 1.19 & 1.30 & $1.25^{\mathrm{b}}$ & 2.03 & 2.15 & $2.09^{\mathrm{a}}$ \\
\hline Mean & $1.08^{\mathrm{A}}$ & $1.14^{\mathrm{A}}$ & & $1.91^{\mathrm{A}}$ & $2.03^{\mathrm{A}}$ & \\
\hline Control & 0.69 & 0.73 & $0.71^{\mathrm{d}}$ & 1.25 & 1.38 & $1.32^{\mathrm{d}}$ \\
\hline $\mathbf{L S D}_{\text {straw }}=\mathbf{0 . 0 5}$ & & & & $\mathbf{L S D}_{\text {straw }}=\mathbf{0 . 0 9}$ & & \\
\hline $\mathrm{LSD}_{\text {nitrogen dose }}=\mathbf{0 . 0 7}$ & & & & $L_{\text {nitrogen dose }}=0.10$ & & \\
\hline LSD $_{\text {interaction }}=0.006$ & & & & LSD $_{\text {interaction }}=0.010$ & ns & \\
\hline
\end{tabular}

(RS) composted rice straw neutralized by sulphuric acid, (RC) composted rice straw neutralized by citric acid, (CS) composted corn straw neutralized by sulphuric acid, (CC) composted corn straw neutralized by citric acid, ns: not significant, the same letters meaning insignificant effect.

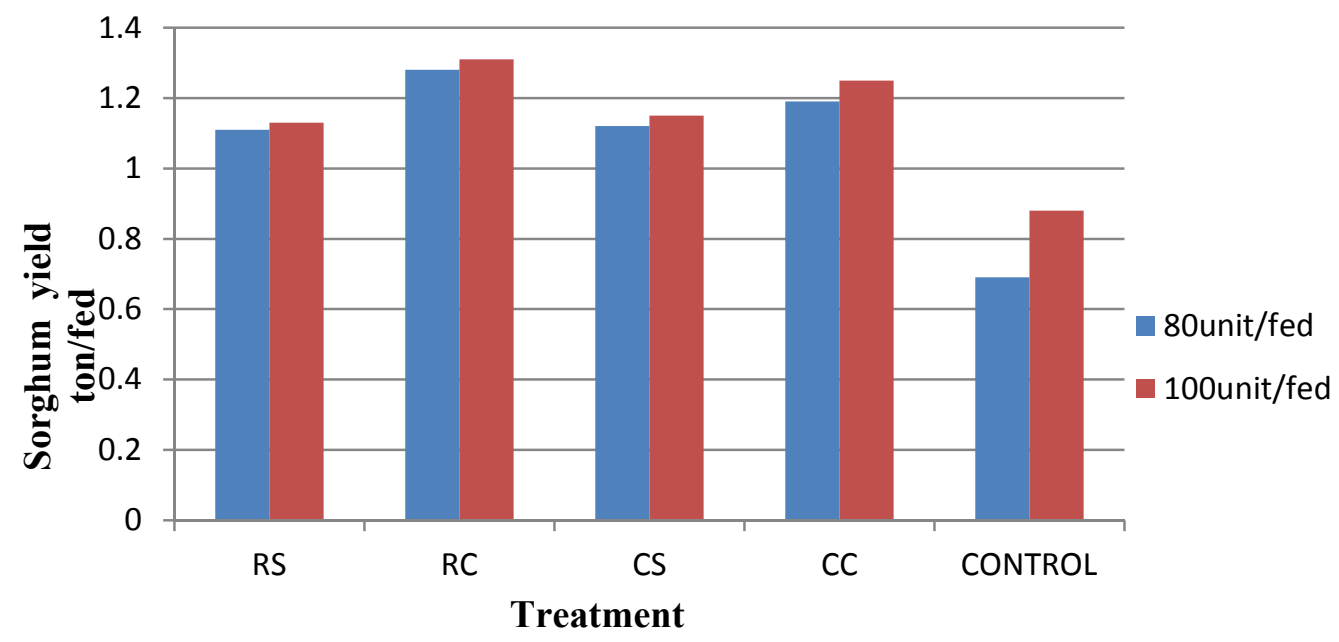

Fig. 1: Average yield of sorghum crop (ton fed ${ }^{-1}$ ) during the first season of cultivation under the effect of different composted materials.

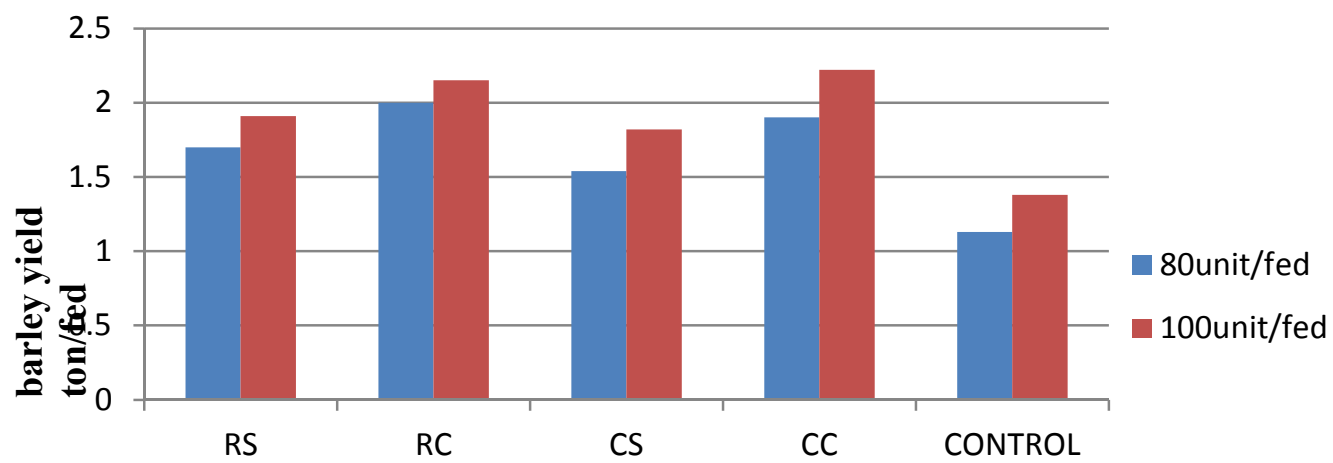

Treatment

Fig. 2: Average yield of barley crop (ton fed ${ }^{-1}$ ) during the second season of cultivation under the effect of different composted materials. 
Also they found that wheat straw yield increased by 169-236 \% when the compost was applied in the first season and by $19-128 \%$ in the following season, due to the residual effects of compost. The added compost, recommended chemical fertilizer and their combine to the studied soil had significant effects on each of productivity in the winter season (fennel crop) and in the second season (pearl millet crop) (Hoda 2019). These trends support the idea that compost has a residual effect on the soil and crop productivity, if growers are able to replace some fertilizer with compost, they may be able to save money by making their own compost or purchasing it locally (Jackson et al., 2013).

\subsection{Differentiation between different types of the composted materials overall experimental results:}

From the after mentioned data, it is concluded that the (RC) and (CC) composted materials gave the highest effect on each of soil chemical properties, nutrient availability and crops yield than each of (RS) and (CS) compared to control. That may be return to the humification and residual fibers percent of the two types of straw where rice straw recorded a higher humification and lesser residual fibers percent than corn straw as shown in Table (5), where the recommended values were $10.73 \%$ and $48.01 \%$ for rice straw and $8.67 \%$ and 51.20 $\%$ for corn straw, respectively. Indeed the application of granular corn straw effectively improved the soil humus content and humic acid structural characteristics and is thus highly recommended (Chen et al., 2020). Combinations of water treatment residues (WTR)and rice straw compost to soils had a greater effect on increasing yield and improved the efficiency of WTR on soil properties ( Mahmoud et al.,2013). Many studies have shown that there are many functional groups on the surface of HA molecules (Xu et al., 2008). These functional groups have strong potentials to bind with soil nutrients, which can effectively retain soil nutrients and reduce nutrient loss in the soil ( $\mathrm{Li}$ et al., 2014). HA also plays an important role in soil environmental health by influencing the transport and passivation of heavy metals in the soil (Li et al., 2014).

Also the composted straws which neutralized by citric acid effectively enhanced each of chemical properties, available nutrients and crops yield than the neutralized by sulphuric acid one. That may be due to that citric acid can act as chelating agent for essential cations which maintain the soil nutrients more soluble and available to plant to a longer time than sulphuric acid which forms leachable sulphate salts. The results agreed with Goli et al.(2012) who stated that The loss of external hydrogen atoms enhances citric acid's ability to act as a chelate and form complexes around positively charged ions such as metals, effectively removing these cations from solution. Tusei, (2019) in his study hypothesized that after being exposed to increasing increments of citric acid concentration, wheat-grass plants would contain higher amounts of macronutrient elements and the soil in which they reside would have a lower $\mathrm{pH}$. Prior experiments suggest that citric acid aids elemental uptake in plants by forming a complex around the cation (Senden et al. 1994). This effectively increases both essential and nonessential nutrient availability to plants (Zhang et al. 2018). Plants often secrete organic acids from their roots in order to complex free metallic ions and draw the element up to their shoots (Wang et al. 2017).

\section{Conclusion}

Base pre-treatment incubation process of both rice straw and corn straw followed by neutralization by sulphuric and citric acids then combined them with soil showed a positive effect on soil chemical properties, such as $(\mathrm{EC}, \mathrm{pH}$, and organic matter $\mathrm{OM} \%)$ and nutrients availability (NPK) compared with un amended soil. The discussed data emphasized that the (RC) and (CC) possessed the major effect on both soil chemical properties and nutrients availability than the (RS) and (CS) compared to control. Also the process succeeded to reduce the humification time period of different straws through four weeks. The effectiveness of the different composted materials on releasing soil nutrient and improving chemical soil properties had a clear effect on increasing Sorghum crop yield during the first season which followed the order; $(\mathrm{RC})>(\mathrm{CC})>(\mathrm{RS})>(\mathrm{CS})>$ untreated soil. Whereas this effectiveness gave small synergistic impact through the second season on barely crop yield. 


\section{References}

Abedi T, A. Alemzadeh and S.A. KazemeIni, 2012. Effect of organicand inorganic fertilizers on grain yield and protein banding pattern of wheat. Aust J. Crop Sci., 4:384-389.

Ahmed, O.H., M.H. Husni, A.R. Anuar, M.M. Hanafi and E.D.S. Angela, 2004. A modified way of producing humic acid from composted pineapple leaves. J. Sustain. Agric. 25: 129-139.

Akhtar, N., K. Gupta, D. Goyal and A. Goyal, 2016. Recent advances in pretreatment technologies for efficient hydrolysis of lignocellulosic biomass. Environmental Progress and Sustainable Energy, 35(2): 489-511.

Alvira, P., E. Tomás-Pejó, M. Ballesteros and M.J. Negro, 2010. Pretreatment technologies for an efficient bioethanol production process based on enzymatic hydrolysis: A review. Bioresour. Technol., 101(13): 4851-4861.

Angellova, V.R., V.I. Akova, N.S. Artinova, and K.I. Ivanov, 2013. The effect of organic amendments on soil chemical characteristics. Bulg. J. Agric. Sci., 19: 958-971.

Awad, E.M., 2002. Effect of compost and some bio-fertilizers on growth, yield and quality of potato crops (Solanumtubersum, L.). J. Agric. Sci, Mansoura, Univ., 27(8): 5525-5537.

Behera, S., R. Arora, N. Nandhagopal, and S. Kumar, 2014. Importance of chemical pretreatment for bioconversion of lignocellulosic biomass. Renew. Sust. Energy Rev. 36: 91-106.

Bremner, J. M. and C.S. Mulvaney, 1982. Nitrogen-total. In Methods of Soil Analysis, Part 2, Chemical and Microbiological Properties, 2nd edn (Eds Page A.L, Miller R.H. and Keeney D.R.), pp. 595-624. Madison, WI: American Society of Agronomy.

Campbell, C.A., E. Paul, D.A. Rennie, and P. McCallum, 1967. Applicability of the carbondating method of analysis to soil humus studies. Soil Sci., 104: 217-24.

Ceccanti, B., G. Masciandaro, and C. Macci, 2007. Pyrolysis-gas chromatography to evaluate the organic matter quality of a mulched soil. Soil Till. Res. 97: 71-78.

Chakim, A.U.M., M. Wanti, S. Siswanto, and S. Purnomo, 2020. Humic acid characterization in soil from various land uses in Tutur District, Pasuruan Regency of East Java. Journal of Degraded and Mining Lands Management, 7: 2279-2286.

Chandra, R.P., R. Bura, W.E. Mabee, A. Berlin, X. Pan, and J.N. Saddler, 2007. Substrate pretreatment: The key to effective enzymatic hydrolysis of lignocellulosics? Biofuels, Springer Berlin/Heidelberg, 67-93.

Chen, X., J. Wu, and Y. Opoku-Kwanowaa, 2020. Effects of Returning Granular Corn Straw on Soil Humus Composition and Humic Acid Structure Characteristics in Saline-Alkali Soil. Sustainability, 12: 1005.

Cottenie, A., M. Verloo, L. Kiekens, G. Velghe and R. Camerlynck, 1982. Chemical Analysis of Plants and Soils. Laboratory of Analytical and Agrochemistry, State Univ., Ghent, Belgium.

Crecchio, C., M. Curci, M. Pizzigallo, P. Ricciuti, and P. Ruggiero, 2004. Effects of municipal solid waste compost amendments on soil enzyme activities and bacterial genetic diversity. Soil Biology \& Biochemistry, 36: 1595-1605.

Dote, Y., S.Y. Yokoyama, and T. Minowa, 1993. Thermochemical liquidization of dewatered sewage sludge. Biomass Bioenergy, 4(4): 243-4.

Eghball, B., 1999. Liming effects of beef cattle feedlot manure or compost. Commun. Soil Sci. Plant Anal., 30: 2563-2570.

EL-Etr, W.T., L.K.M. Ali and E. L. EL-Khatib, 2004. Comparative effects of bio-compost and compost on growth, yield and nutrients content of pea and wheat plants grown on sandy soils. Egypt. J. of Agric. Res., 82(2): 73-94.

El-Maaz, E.I.M., H.M.R. Ahmed, and Kh. A. Shaban, 2014. Soil chemical properties and wheat productivity as affected by organic, bio-fertilization and cultivation methods in saline soil. Minufiya, J. Agric. Res., 39 (6): 1955-1968.

Emir, C., M.J. Muñoz, R. Martín, I. Caro, C. Curbelo, A.B. Díaz, 2014. Alkaline and alkaline peroxide pretreatments at mild temperature to enhance enzymatic hydrolysis of rice hulls and straw. Bioresource Technology, 167: 1-7. 
Gee, G.W. and J.W. Bauder, 1986. Particle size analysis in Methods of Soil Analysis (Klute, Ed. Part1. Agron.9. 15: 383- 409. Am. Soc. Agron. Madison. Wisconsin . U.S.A).

Ginting, D., A. Kessavalou, B. Eghball, and J.W. Doran, 2003. Greenhouse gas emissions and soil indicators four years after manure and compost applications. J. Environ. Qual., 32: 23-32.

Goli, M.B., M. Pande, and N. Bellaloui, 2012. Effects of chelating agents on protein, oil, fatty acids, and minerals in soybean seed. Agricultural Sciences, 3: 517-523.

Hideno, A., 2017. Short-time alkaline peroxide pretreatment for rapid pulping and efficient enzymatic hydrolysis of rice straw. Bioresource Technology, 230: 140-142.

Hoda, A. Elia, 2019. Effect of compost and chemical fertilizer addition on improving calcareous soil properties in Rassudrarea. Middle East Journal of Agriculture Research, 8(4): 1133-1141.

Ibarra-Díaz, N., J.F. Castañón-Rodríguez, J. Gómez-Rodríguez, and M.G. Aguilar-Uscanga, 2020. Optimization of peroxide-alkaline pretreatment and enzymatic hydrolysis of barley straw (Hordeum vulgare L.) to produce fermentable sugars using a Box-Behnken. Biomass Conversion and Biorefinery, https://doi:10.1007/s13399-020-00853-4.

Jackson, M .L., 1967. Soil Chemical Analysis. Prentice - Hall, Inc. Englewood Cliffs, N.J.

Jackson, M.L., 1973. Soil Chemical Analysis, Constable and Co. Ltd. Prentice Hall of India Pvt. Ltd. New Delhi., 10-114.

Jackson, T.L., W. Brinton, D.T. Handley, M. Hutchinson and M. Hutton, 2013. Residual Effects of Compost Applied to Sweet Corn Over Two Crop Seasons. Journal of National Association of County Agricultural Agents (NACAA), 6(1): 1-6.

Jiangkuan, N., X. Chen, G.X. Wan, M.S. Lashari, Y. Wang, Z. Guo, and Z. Du, 2016. Effects of applying flue gas desulfurization gypsum and humic acid on soil physicochemical properties and rapeseed yield of a saline-sodic crop land in the eastern coastal area of China. J. Soils Sediments, 16: 38-50.

Jin, Y., T. Huang, W. Geng, and L. Yang, 2013. Comparison of sodium carbonate pretreatment for enzymatic hydrolysis of wheat straw stem and leaf to produce fermentable sugars. Bioresour. Technol., 137: 294-301.

Johnson, G. A., J.G. Davis, Y.L. Qian and K.C. Doesken, 2006. Topdressing Turf with Composted Manure Improves Soil Quality and Protects Water Quality. Soil Sci. Soc. of America J., 70: 2114-2121.

Khaled, H. and H.A. Fawy, 2011. Effect Of Different Levels Of Humic Acids On The Nutrient Content, Plant Growth, and Soil Properties Under Conditions Of Salinity. Soil \& Water Res., 6(1): 21-29.

Kim, S., and B.E. Dale, 2004. Global potential bioethanol production from wasted crops and crop residues. Biomass and Bioenergy, 26(4): 361-375.

Kim, T.H. and Y.Y. Lee, 2005. Pretreatment of corn stover by soaking in aqueous ammonia. Appl. Biochem. Biotechnol. 124: 1119-1132.

Kumar, R., and C.E. Wyman, 2009. Effects of cellulase and xylanase enzymes on the deconstruction of solids from pretreatment of poplar by leading technologies. Biotechnol. Prog., 25: 302-314.

Lakhdar, A., M. Rabhi, T. Ghnaya, F. Montemurro, N. Jedidi and C. Abdelly, 2009. Effectiveness of compost use in salt-affected soil. J. Hazard. Mater., 171: 29-37.

Lglesias-Jimenez, E., and C. Alvarez, 1993. Apparent availability of nitrogen in composted municipal refuse. Biology and Fertility of Soils, 16: 313-3168.

Li, J.J., C.Z. Li, L.J. Gao, B.S. Liu, D.S. Liu, and G.Y. Zou, 2014. Impact of different organic fertilizers on soil humus, microbiomass and quality of cabbage. Adv. Mater. Res., 955: 628-632.

Li, Q., L. Sun, Y. Zhang, Y. Qian, and J. Zhai, 2011. Characteristics of equilibrium, kinetics studies for adsorption ofHg (II) and Cr (VI) by polyaniline/humic acid composite. Desalination, 266: 188-194.

Lund, Z.F., and B.D. Doss, 1980. Residual effects of dairy cattle manure on plant growth and soil properties. Agron. J. 72: 123-130. 
Mahmood, H., M. Moniruzzaman, T. Iqbal, and M.J. Khan, 2019. Recent advances in the pretreatment of lignocellulosic biomass for biofuels and value. Current Opinion in Green and Sustainable Chemistry, 20: 18-24.

Mahmoud, I., R. Paul, R. Esawy, and E. Mohamed, 2013. Rice Straw Composting and Its Effect on Soil Properties. Compost Science \& Utilization, 17: 146-150.

Millett, M.A., A.J. Baker, and L.D. Satter, 1985. Pretreatments to enhance chemical, enzymatic and microbiological attack of cellulosic materials. Biotechnol Bioeng Symp., 5: 193-219.

Mindari. W, P. EdiSasongko, Z. Kusuma, and A. Nurul, 2019. Efficiency of Various Sources and Doses of Humic Acid on Physical and Chemical Properties of Saline Soil and Growth and Yield of Rice. The 9th International Conference on Global Resource Conservation (ICGRC) and AJI from Ritsumeikan University AIP Conf. Proc., 030001.

Mona, H.M. Kenawy, 2017. Impact of Amino Acids and Humic Substances Application on Some Soil Chemical Properties Along with Nutritional Status and Productivity of Wheat Grown under Saline Conditions. J. Soil Sci. and Agric. Eng., Mansoura Univ., 8(6): 231240.

Motavalli, P.P., K.A. Kelling, and J.C. Converse, 1989. First-year nutrient availability from injected dairy manure, J. Environ. Qual., 18: 180-185.

Nardi, S., F. Morari, A. Berti, M. Tosoni, and L. Giardini, 2004. Soil organic matter properties after 40 years of different use of organic and mineral fertilizers. Eur. J. Agron., 21: 357367.

Nelson D.W and L.E. Sommers, 1982. Methods of Soil Analysis: Part 2 Chemical and Microbiological Properties, 9.2.2, Second Edition, Chapter 29, Total carbon, organic carbon and organic matter, 539-579.

Nigus, D., B. Wondimu, T. Sitot, Z. Feras, and S. Rolf, 2014. Current and residual effects of compost and inorganic fertilizer on wheat and soil chemical properties. Nutrient Cycling in Agroecosystems, 100: 357-367.

Page, A.L., R.H. Miller and D.R. Keeny, 1982. Methods of Soil Analysis. Part2. Chemical and Microbiological Properties. Second Edition, Madison, Wisconsin, USA.

Patel, V., M. Desai, and D. Madamwar, 1993. Thermochemical pretreatment of water hyacinth for improved biomethanation. Appl Biochem Biotechnol, 42: 67-74.

Penaud, V., J.P. Delgene's and R. Moletta, 1999. Thermo-chemical pretreatment of a microbial biomass: influence of sodium hydroxide addition on solubilization and anaerobic biodegradability Enzyme and Microbial Technology, 25: 258-263.

Qing, Q., Q. Guo, L. Zhou, X. Gao, X. Lu, and Y. Zhang, 2017. Comparison of alkaline and acid pretreatments for enzymatic hydrolysis of soybean hull and soybean straw to produce fermentable sugars. Industrial Crops \& Products, 109: 391-397.

Rady, M.M., W.M. Semida, and K.A. Hemida, 2016. The effect of compost on growth and yield of Phaseolus vulgaris plants grown under saline soil. Int J Recycl Org Waste Agricult., 5: 311-321.

Rashad, F.M., H.H. Kesba, W.D. Saleh and M.A. Moselhy, 2011. Impact of rice straw composts on microbial population, plant growth, nutrient uptake and root-knot nematode under greenhouse conditions. African J. of Agric. Res., 6 (5): 1188-1203.

Rodríguez, A., A. Mora, L. Serrano, J. Labidi, and L. Jiménez, 2008. Rice straw pulp obtained by using various methods. Bioresour. Technol., 99 (8): 2881-2886.

Sarwar, G, H. Schmeisky, N. Hussain, S. Muhammad, M. Ibrahim and E. Safdar, 2008. Improvement of soil physical and chemical improvement with compost application in rice-wheat cropping system. Pak J. Bot., 40: 275-282.

Sawayama, S., S. Iroue, T. Yagishi, T. Ogi, S.Y. Yokoyama, 1995. Thermo chemical liquidization and anaerobic treatment of dewatered sewage sludge. J. Fermentation Bioeng., 79 (1): 300-02.

Senden, M.H.M., A.J.G. van der Meer, T.G. Verburg, H.T. Wolter-beek, 1995. Citric acid in tomato plant roots and its effect on cadmium uptake and distribution. Plant \& Soil, 171: 333-339.

Sheikh, M.M., C.H. Kim, H.H. Park, H.G. Nam, G.S. Lee, H.S. Jo, J.Y. Lee and J.W. Kim, 2015. A synergistic effect of pretreatment on cell-wall structural changes in barley straw 
(Hordeum vulgare L.) for efficient bioethanol production. Journal of the Science of Food and Agriculture, 95(4): 843-850.

Stuckey, D.C., and P.L. MacCarty, 1978. Thermochemical treatment of nitrogenous materials to increase methane yield. Biotechnol Bioeng; 8: 219-33.

Tambone, F., P. Genevini, F. Adani, 2013. The Effects of Short-Term Compost Application On Soil Chemical Properties and on Nutritional Status of Maize Plant. Compost Science \& Utilization, 15: 176-183.

Tarkow, H. and C.W. Feist, 1969. A Mechanism for improving the digestibility of lignocellulosic materials with dilute alkali and liquid ammonia, in cellulases and their applications, American Chemical Society, 95: 197-218.

Tusei, C.L. 2019. The effects of citric acid on $\mathrm{pH}$ and nutrient uptake in Triticum aestivum. Idea Fest Journal: Interdisciplinary Journal of Creative Works \& Research from Humboldt State University 3: 31-35.

Wang, S., Q. Dong, and Z. Wang, 2017. Differential effects of citric acid on cadmium uptake and accumulation between tall fescue and Kentucku bluegrass, Ecotoxicology and Environmental Safety, 145: 200-206.

Watanabe, F.S., and S.R. Olsen, 1965. Test of an ascorbic acid method for determining phosphorus in water and $\mathrm{NaHCO}_{3}$ extracts from soil. Soil Science Society of America Proceedings, 29: 677-678.

Weber J, A. Karczewska, J. Drozd, M. Licznar, S. Licznar, E. Jamroz, and A. Kocowicz, 2007. Agricultural and ecological aspects of asandy soil as affected by the application of municipal solid wastecomposts. Soil Biol. Biochem., 39: 1294-1302.

Whitfield, M.B., M.S. Chinn, and M.W. Veal, 2012. Processing of materials derived from sweet sorghum for biobased products. Ind. Crops Prod., 37: 362-375.

$\mathrm{Xu}, \mathrm{D}$., X. Zhou, and X. Wang, 2008. Adsorption and desorption of Ni2+on Namontmorillonite: Effect of $\mathrm{pH}$, ionic strength, fulvic acid, humic acid and addition sequences.Appl. Clay Sci., 39: 133-141.

Zhang, X., B. Zhong, M. Shafi, J. Guo, C. Liu, H. Guo, D. Peng, Y. Wang, and D. Liu, 2018. Effect of EDTA and citric acid on absorption of heavy metals and growth of moso bamboo. Environmental Science \& Pollution Research, 25: 18846-18885.

Zhu, J., C. Wan, and Y. Li, 2010. Enhancing soil state anaerobic digestion of corn stover by alkaline pretreatment. Biosour. Technol., 101: 7523-7528. 